\title{
Study of the Factors Influencing the Shallow Groundwater Quality in Two Settlements with Different Characteristics
}

\author{
György Szabó, Tímea Vince and Éva Bessenyei \\ University of Debrecen \\ Hungary
}

\section{Introduction}

Recently, clean water became one of the most important natural resources. It is also proven by the fact that the fight for water often causes conflicts, even wars as well (Sultana, 2011). Although the water resources of the Earth are large, most of the water can be found in oceans $(96.6 \%)$, and this water is hardly available for the humanity since the desalination is a very expensive process and the transportation of the cleaned water to the inner continent is also difficult. Only $3.4 \%$ of the hydrosphere is fresh water; most of it is also hardly available such as the water stored in the polar ice caps or the water resources found in the lithosphere deeper than $5 \mathrm{~km}$ (Rakonczai, 2008). Easily available water resources are the surface waters of the continents (rivers and lakes), and the groundwater such as shallow groundwater, karstic water and deep groundwater.

Unfortunately, in the last decades the condition of the fresh water resources has worsened. Especially the contamination of the surface water resources is significant in many places, but the groundwater resources are also often in danger (Howden et al., 2009; Oprean et al., 2009; Pál et al., 2009; Szalai, 2004). The mostly endangered groundwater resource is the shallow groundwater since the contaminants can easily get into it due to its little depth. Karstic water resources are also relatively sensitive since contaminants can get into the water through the cracks of the rock. Deep groundwater is less sensitive to contaminants due to the greater depth, especially when there is a confining layer (or layers) above it. Unfortunately, this water reserve of strategic significance has already become contaminated in several countries of the Earth.

Shallow groundwater is one of the most important water resources in several countries, although the use of it is decreased in the developed countries in the last decades. For example in Hungary, in the 1950s shallow groundwater was the most significant water resource, but recently only $6 \%$ of the drinking water derives from shallow groundwater (Steiner, 2010); the decrease is owing to the serious contamination. In the settlements several pollution resources can endanger the condition of shallow groundwater, but contaminants can also derive from agriculture in the outer areas.

In the settlements, one of the most important contaminants is domestic sewage that can cause significant pollution in settlements where the sewer network is not constructed. 
Contamination occurs since the septic tanks, where domestic sewage is collected, are not supplied with adequate insulation therefore sewage can infiltrate into the soil (Szabó et al., 2010). Besides, significant pollution sources are the out-of-date landfills and sewage disposals that are not supplied with adequate insulation, but the industrial activities can also cause serious contaminations. The residues of fertilizers and insecticides used in the agriculture can also appear in the shallow groundwater. Moreover, the manure deriving from livestock farming, if the storage is not proper, can also endanger the shallow groundwater.

The most common contaminants of the shallow groundwater are mainly the different compounds of nitrogen (ammonium, nitrite and nitrate). Additionally, phosphates are also important contaminants; they can derive from sewage, soil or the decomposition of the organic materials. Phosphates usually appear as inorganic orthophosphate ions in shallow groundwater. Bacterial pollution also causes problems; the sources of infection can be the domestic sewage and the livestock farms. Near industrial areas, shallow groundwater can often be contaminated with heavy metals and different hydrocarbon derivatives (Steiner, 2010).

Several papers have been published regarding the pollution of shallow groundwater, the factors influencing the contamination and the risks resulted from contamination. Several authors emphasized the determinant role of the agricultural contaminants. Jang and Liu (2005) examined the nitrate and ammonium contamination of the water resources situated in different depth in the alluvium of the Choushui River, Taiwan. They proved that the main source of pollution was agriculture. Using isotope analyses, Widory et al. (2004) investigated the nitrate pollution sources of the shallow groundwater in the sample sites in the watershed of the River Arguenon, France. They determined that mainly organic manure and sewage infiltrating into the soil cause nitrate pollution. The authors emphasize that in spite of the more and more increasing national and European efforts (EC Directive 91/676/EEC) nitrate deriving from the intensive agriculture is still the most significant contaminant of the shallow groundwater. Cey et al. (1999) also examined the nitrate concentration of the shallow groundwater in agricultural areas. They proved that nitrate mainly derives from organic manure and chemical fertilizers. The authors also showed that when the shallow groundwater leaves the agricultural areas, the nitrate concentration quickly decreases mainly due to denitrification. Goss et al. (1998) studied the pollution of the shallow groundwater in some farms of Ontario, Canada. The authors also examined the factors influencing the degree of contamination and proved, based on the examinations of 1292 wells, that the degree of nitrate pollution principally depends on the depth of the shallow groundwater. The concentration was significantly lower in the deeper wells. Warner et al. (2008) drew similar conclusion, they carried out water quality examinations in Kathmandu valley, Nepal. They proved that regarding nitrate and bacterial contamination shallow groundwater, that is closer to the surface, was the most polluted. This means serious health risk since in the examined area $50 \%$ of the inhabitants used shallow groundwater as drinking water. Chettri and Smith (1995) also studied the pollution of shallow groundwater in Nepal. They experienced that nitrate contamination derived mainly from septic tanks and waste disposal, but agricultural pollution was not significant.

Muñoz-Carpena et al. (2005) examined the nitrate, orthophosphate and total phosphate concentration of the shallow groundwater in an agricultural watershed near the Everglades 
National Park. They proved that the temporal changes of the concentration of the examined water quality parameters are significantly influenced by the rainfall and the depth of the shallow groundwater. It was also determined that the concentration of the contaminants increases after intensive rainfalls due to the increased leaching.

Other authors drew similar conclusions regarding the nitrate contamination of the shallow groundwater wells examined in the rural area of SW Nigeria (Adekunle et al., 2007). They observed that the water of the wells was more polluted in the wet season than in the dry season. In the area the most important pollution sources are the waste landfills and the sewage disposal. Moreover, the authors also proved that the contamination occurs mainly within the $200 \mathrm{~m}$ radius of the pollution sources. In this zone the nitrate concentration of the water exceeded the limit value determined for drinking water by the WHO. This means serious health risk since the population consume mainly the water of the wells. In Wisconsin, USA, Knobeloch et al. (2000) examined the effect of the nitrate content of drinking water on infants. Two cases were demonstrated when the infants have the socalled "blue baby" syndrome. In both cases the babies consumed the water of the private well created by the families, and this resulted in their sickness. In the surroundings of the polluted wells there were agricultural areas, and the high nitrate concentration of the water presumably derived from nitrogen-rich fertilizers. It is also mentioned in the study that in the USA, between 1979 and 1996, 6 children died in methemoglobinemia caused by the nitrate contamination of the shallow groundwater. Since 1945, 3000 deaths are known in the world, almost half of them occurred in Hungary (Barzilay et al., 1999). However, the high nitrate concentration of the shallow groundwater is dangerous not only for infants but for the adults as well; higher concentrations also have harmful effects on adults. Similar to children, ruminant domestic animals such as goat, sheep and cow are also sensitive to methemoglobinemia since their digestive system quickly transforms nitrate to nitrite (Barzilay et al., 1999).

In this chapter two settlements with different characteristics were examined. We supposed that regarding the quality of shallow groundwater there is significant difference between the two settlements due to the different natural and social-economic characteristics. Thus, our objective was to survey the contamination of the shallow groundwater, to examine the factors influencing the quality of shallow groundwater, and to determine the most determinant factor in terms of water quality. At last, we also intend to survey the health risks related to the use of shallow groundwater.

\section{Sample sites}

Our examinations were carried out in a small town of Eastern Hungary, Mikepércs, and in a Western Ukrainian town, Beregszász (Fig. 1).

Mikepércs is situated in the eastern part of Hungary, about $5 \mathrm{~km}$ south from Debrecen. Mikepércs has diverse pedological conditions as the settlement is situated in the boundary of the Hajdúság and the Nyírség. The loess area of the Hajdúság extends to the western part of the settlement where chernozem soils were formed. Soils of sandy texture can be found in the greater part of the settlement that belongs to the area of the Nyírség. These soils are much more sensitive than the chernozems: in addition to the coarser grain size distribution the less organic matter content and the weaker buffering capacity of the sandy soils also 
contribute to the considerable sensitivity to contaminants. The depth of the water table in Mikepércs is 1-3 meter but in the higher reliefs more than 5 meter deep water table can occur. The shallow groundwater flows from the north-east to the south-west, towards the Kondoros stream running near the west part of the village.

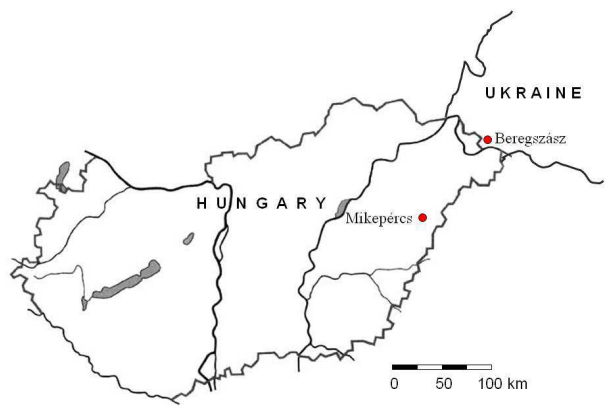

Fig. 1. The localization of the examined settlements

In the settlement of 4000 inhabitants the water supply system is almost $100 \%$ constructed but the construction of the sewer system has begun only in the second half of 2006, and the installation was executed only after the examinations, thus the positive effects of the sewerage cannot be demonstrated in this examination series. The inhabitants use the water of the dug wells to water gardens and domestic animals, even to wash cars, but sometimes, mainly elder people drink water from the wells.

Beregszász can be found in the western part of Ukraine, Transcarpathia, almost $50 \%$ of its inhabitants are Hungarian. The town is situated in the landscape border of the inner volcanic belt of the Eastern Carpathians, and the Great Hungarian Plain. The Bereg Plain is very fertile since the River Tisza and its tributaries regularly flooded the area over thousands of years, and humus-rich soils of good quality could be formed on the sediment.

The rivers that can be found in the surroundings of Beregszász are lower-course rivers. The River Tisza flows approximately $9 \mathrm{~km}$ from the town along the Ukrainian-Hungarian border. The Vérke canal flows through Beregszász and connects the Borzsa and the Latorca rivers. Similarly to most of the plain areas in Transcarpathia, the shallow groundwater is in the depth of 3-7 $\mathrm{m}$ in Beregszász; above the water there are fine-grained sediments, often clayey confining layers that make the infiltration of the contaminants into the shallow groundwater from the surface more difficult (Molnár, 2009).

Beregszász is the centre of Beregszász district and the population of the town was 25200 in 2008 (Molnár, 2009). The sewer network is partially constructed in the town, $62.7 \%$ of the residential area is supplied with sewer system. Unfortunately, the treatment of the collected sewage is not adequate; it is observable in the Vérke Canal since it is the receiver. The water supply system is also not entirely constructed in the settlement, therefore the inhabitants do not use shallow groundwater only to water gardens and animals but they cook and wash with it and also drink it. The inhabitants regularly drink from the water of 13 wells of the examined 16 ones. According to our observations, the inhabitants occasionally used shallow groundwater even if they can use tap-water. The main explanation is that they have to pay 
for tap-water, and on the other hand the taste of the water from the wells is considered to be better than tap-water.

\section{Methods}

In our research the water quality of dug shallow groundwater wells was examined. In Mikepércs 14 and in Beregszász 16 wells were chosen; we tried to cover the whole area of the settlements (Fig. 2 and 3).

Water samples were examined monthly: we have a two-year data set regarding Mikepércs (from June 2005 to June 2006 and from July 2007 to July 2008), and in the case of Beregszász the examinations lasted a year (from April 2009 to March 2010). The samples were transported in hermetically closed plastic flacons to the geography laboratory of the University of Debrecen.

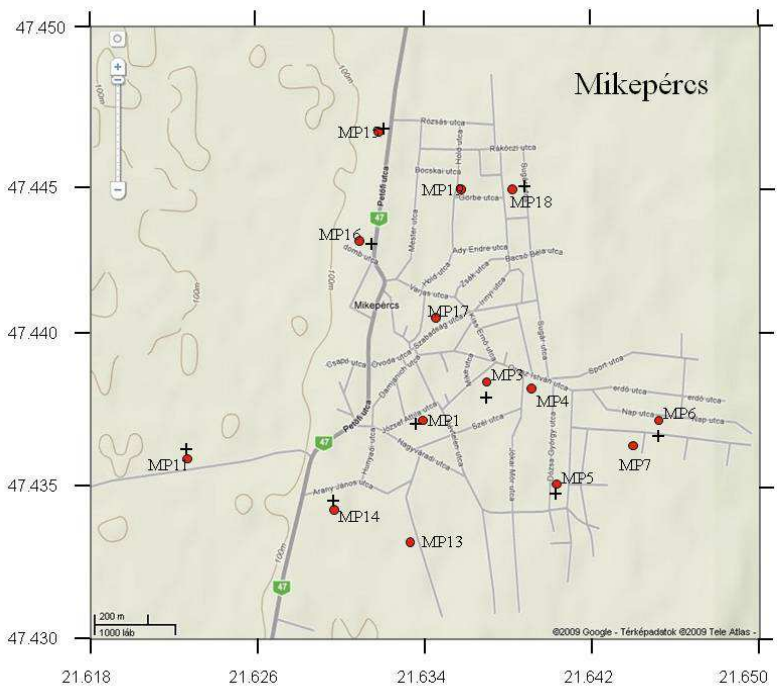

Fig. 2. The location of the groundwater sample wells in Mikepércs (The soil samples are marked by the crosses)

Electric conductivity and temperature were measured in situ with a Schott electric conductometer. The depth of the water table was also determined during the sampling. The determination of nitrite, nitrate, orthophosphate, ammonium and organic matter, and the measurement of the $\mathrm{pH}$ were carried out in the laboratory a day after the sampling (Literáthy, 1973).

Among the natural factors influencing the shallow groundwater quality, soil characteristics were examined. Soil samples were collected from the surroundings of 13 wells, from approximately a meter below the water table. Samples were taken from every $20 \mathrm{~cm}$ layers and were examined in the geography laboratory of the University of Debrecen, according to the Hungarian standards. We determined the grain size distribution with Köhn-pipette 
(MSZ, 1978a), the humus content after Tyurin's scheme (MSZ 1977), and the pH with an electric pH-meter (MSZ 1978b). The determination of the $\mathrm{CaCO}_{3}$-content was carried out with Scheibler-calcimeter (Ballenegger \& Di Gléria, 1962). Additionally, the rainfall and the depth of shallow groundwater were also considered.

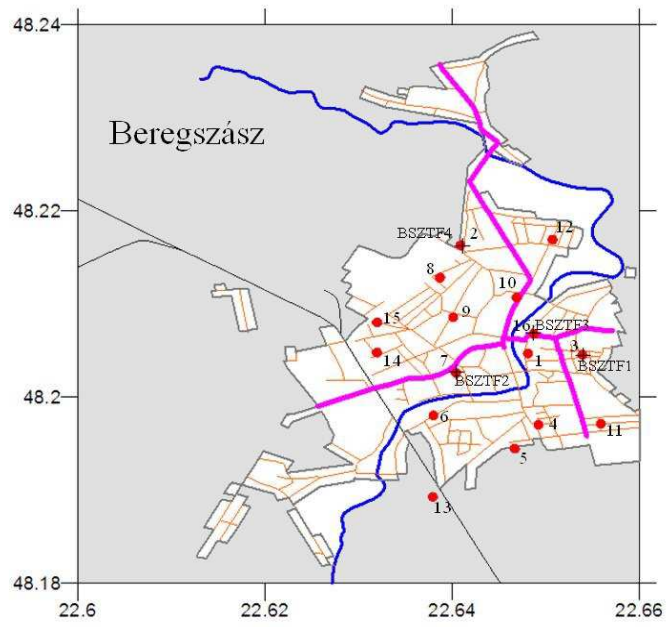

Fig. 3. The location of the groundwater sample wells in Beregszász (The soil samples are marked by the crosses)

Among the social-economic factors we examined the sewer network, the condition of the septic tanks, the construction of the water supply system, the use of water and the sources of pollution near the wells.

The results were saved in an Excel database, and the diagrams were also made with this software. In the course of the statistical analyses normality test were executed with Kolmogorov-Smirnov test. Since most of the data were not normal distribution data, Spearman correlation coefficient was applied during the correlation analysis. SPSS 8.0 software was used in the statistical analyses and to make further diagrams. A questionnaire survey was carried out in order to map the sources of pollution, and regarding the use of the water deriving from the wells.

\section{Results and discussion}

\subsection{The evaluation of the factors influencing the shallow groundwater condition}

First, the natural factors are studied, and then the role of the anthropogenic factors is surveyed as influencing factors.

Among the natural factors, the depth of the shallow groundwater is important since if the shallow groundwater can be found deep, then the infiltration of the contaminants is more difficult. There is significant difference between the two examined settlements because in Mikepércs the water table was between $1.5 \mathrm{~m}$ and $2.5 \mathrm{~m}$ during the examinations (Fig. 4). 
However, in Beregszász the depth of water was between $3 \mathrm{~m}$ and $5 \mathrm{~m}$, but in some wells there were deeper water tables than $7 \mathrm{~m}$ in the dry periods. Based on this we can say that regarding depth Beregszász is in better situation.

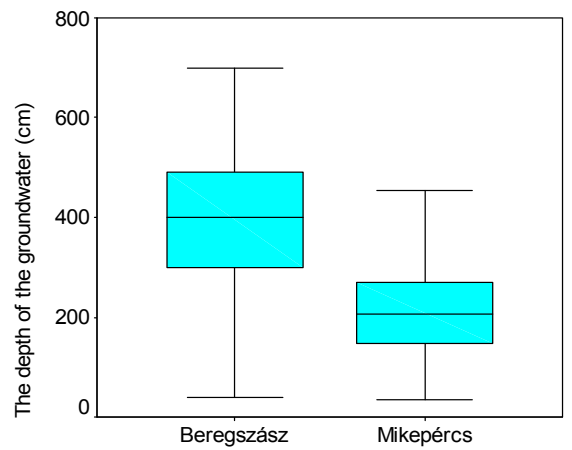

Fig. 4. The depth of shallow groundwater in the examined settlements, based on the data of all the examined wells. (Middle line: median, box: interquartile range, between upper and lower edges: interquartile range by 1.5.)

The role of depth is also proven by the fact that there are significant negative correlations between the concentration of all the examined contaminants and the depth of the shallow groundwater. This means that the deeper shallow groundwater cannot be polluted easily.

Grain size distribution is also an important factor in the contamination of the shallow groundwater. If the soil consists of finer grains, the infiltrating water and dissolved materials, and colloids cannot easily get into the deeper layers of the soil (Nyizsalovszki \& Szabó, 2003). If a soil layer is enriched with smaller grains than $0.002 \mathrm{~mm}$ and becomes clayey, it can be a confined layer that can prevent the transportation of the contaminants into the deeper layers. In order to determine the grain size distribution we collected soil samples from 9 boreholes in Mikepércs and from 4 boreholes in Beregszász above the water table. Based on the results we can say that in Mikepércs, in the cases of the layers above the water-table fine sand $(0.02-0.2 \mathrm{~mm})$ dominates since the percentage of fine sand was more than $80 \%$ in every sample. Therefore, the value of the infiltration coefficient is high. The results of the sampled layers near the wells MP6 and MP11 can be seen in Figure 5. The other samples in the settlement showed similar grain size distribution. Campbell's infiltration coefficient was calculated in every layers of the soil above the water table (Campbell, 1985), and we proved that for example in the surroundings of the well MP6 the infiltrating water reaches the water table in $3 \mathrm{~m}$ depth during 27 hours. In the surroundings of the well MP11 the water from the surface reaches the water table during 33 hours due to the higher percentage of the silt and clay fractions. In the surroundings of the other wells we determined similar infiltration rates.

Examining the soil layers in Beregszász, the results are totally different. It is observable in Figure 6 that the finer grain size dominates in the layers: the joint percentage of the clay $(<0.002 \mathrm{~mm})$ and silt $(0.02-0.002 \mathrm{~mm})$ fractions exceeds $50 \%$. There were soil layers in two sample points where the percentage of the clay fraction was more than $60 \%$, that almost made the given layer confined. For example in the case of BSZTF4 in the layer of the highest 
clay concentration $(200-240 \mathrm{~cm})$ the infiltration coefficient did not reach $2 \mathrm{~cm} /$ day $(1.9$ $\mathrm{cm} /$ day). Based on the infiltration coefficients determined from the sampled layers, in the surroundings of BSZTF3 water needs 18 days to reach the water table in $4 \mathrm{~m}$ depth. Due to the significantly higher clay concentration, water needs 54 days to reach the water table in 3 $\mathrm{m}$ depth near BSZTF4. Thus, it can be proven that in Beregszász it is more difficult for the contaminants to get to the water table, compared to Mikepércs.

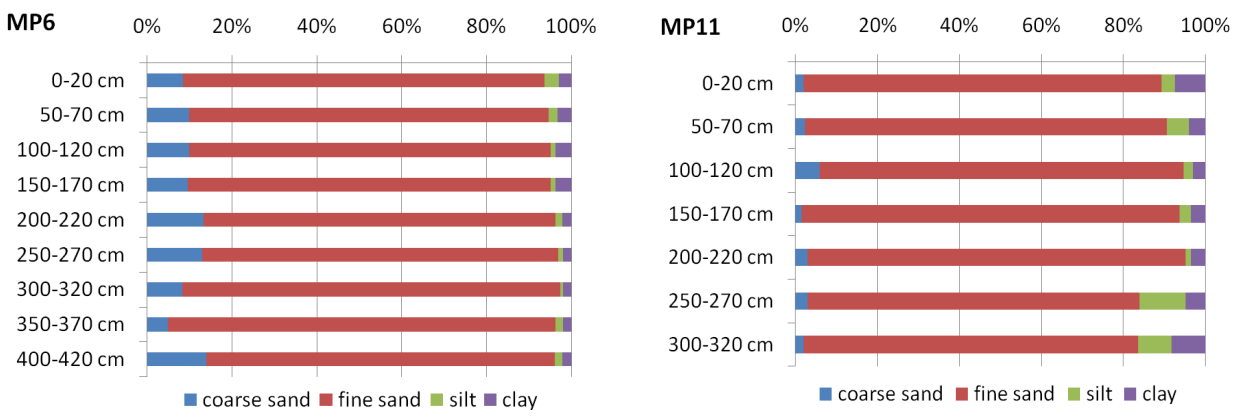

Fig. 5. The grain size distribution diagramms of the soil layers near the wells MP6 and MP11, Mikepércs
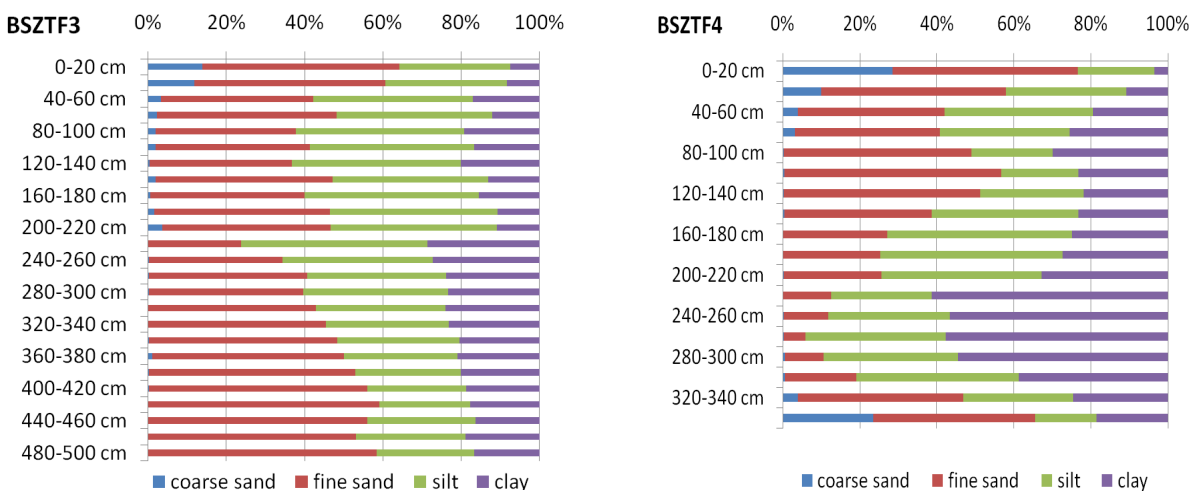

Fig. 6. The grain size distribution of the soil layers near the wells BSZTF3 and BSZTF4, Beregszász

The condition of shallow groundwater can be influenced by the climate of the area. Rainfall has an important role among the climatic factors since contaminants move mainly with the infiltrating water inside the soil layers. In the rainiest areas, leaching is typical of soils: the direction of the water movement in the soil layers is mostly from the surface to the deeper layers. Rainfall also has effects on the depth of water table: when the water table rises in the rainy periods, it comes closer to the contaminants on the surface, and then the leaching pollutants moves the most intensively toward the water table. However, in the cases of the dug wells the dilution of the contaminants can occur due to the water abundance. 
In the surroundings of Mikepércs and Beregszász, the leaching processes that also facilitate the leaching of contaminants into the deeper layers become determinant above the precipitation amount of approximately $500 \mathrm{~mm} /$ year. The precipitation conditions were studied in both settlements in the research periods, and we proved that in Mikepércs, the annual precipitation was $830 \mathrm{~mm}$ in the first research year, and $677 \mathrm{~mm}$ in the second one. These values exceeded the average of many years $(600 \mathrm{~mm})$ that is typical of the region. In Beregszász, the amount of precipitation was $820 \mathrm{~mm}$ in the year of the research, and it is also more than the average of many years $(671 \mathrm{~mm})$ measured in the town.

The problem of sewage is the most important one among the anthropogenic factors; it is the most dangerous factor for the shallow groundwater under the settlements. The proportion of the constructed sewer network has significant effect on the condition of shallow groundwater, but the lack of sewer system by itself does not necessarily mean that the sewage gets into the soil and the shallow groundwater since if the sewage is collected in adequately insulated septic tanks and transported properly, the pollution of shallow groundwater do not occur. Unfortunately, according to our experiences, in the settlements where sewer network is not constructed the septic tanks are not supplied with adequate insulation in many cases, so the collected sewage can infiltrate into the soil, then to the shallow groundwater. In Mikepércs where the sewer network had not been constructed by the time of the examination, the inhabitants collected the sewage in septic tanks. Comparing the quantity of water consumption and the transported sewage we observed that more than $90 \%$ of the sewage infiltrated into the soil. The main cause of this was mainly that the septic tanks were not supplied with adequate insulation, and sewage can easily infiltrate into the soil since the soil consists of coarse grains and its water permeability is very good. In Beregszász, the situation is better since almost the two-third of the settlement is supplied with sewer network but in the non-sewered parts only a little amount of sewage can infiltrate into the shallow groundwater due to the high clay content of the soils. However, we made a questionnaire survey and it turned out that in 10 cases of the 16 examined households the sewage was not collected in septic tanks but the inhabitants pour it into the drainage channel, or in the backyard and the garden. Obviously, these processes also do not endanger significantly the shallow groundwater since the soils in the settlement have bad water permeability so they can provide some protection against the contamination of the shallow groundwater.

The shallow groundwater wells are endangered not only by the domestic sewage but other pollution sources must also be considered. Manure and liquid manure from livestock farming mean considerable contamination, especially when the proper storage of them is not assured. Livestock farming and the related problems are rather typical of Mikepércs since there was livestock farming in the direct surroundings of 12 of the 14 examined wells, while in Beregszász livestock farming could be found in the close surroundings of only 6 of the 16 examined wells. However, manure was collected in proper storage tanks in neither of the settlements, thus the manure and liquid manure could infiltrate into the soil in both towns, and they could easily reach the shallow groundwater in Mikepércs. In Beregszász, contamination deriving from livestock farming was not considerable due to the reasons mentioned above.

Besides livestock farming, gardens can also be pollution sources if the fertilizer scattered in the gardens and the insecticide infiltrate into the soil and reach the water table. In 
Mikepércs, gardens can be found in the surroundings of $86 \%$ of the wells, but fertilizers and insecticides are used in only $25 \%$ of the gardens. In Beregszász, gardens can be found in the close surroundings of only half of the wells, and the use of fertilizers and insecticides are not typical: fertilizer was used in only one garden and insecticide was applied in three gardens. Summarizing the experiences we can say that gardens cause problems rather in Mikepércs than in Beregszász, but their significance is inconsiderable comparing to the problems related to livestock farming and the lack of sewer network.

\subsection{The pollution level of groundwater}

\subsection{1 $\mathrm{pH}$}

There is significant difference between the two settlements regarding $\mathrm{pH}$. In Mikepércs, the $\mathrm{pH}$ of the examined water samples was slightly alkaline, while in Beregszász most of the samples were neutral or slightly acidic, but the measured values (except some of them) were within the interval of the (B) limit values $(\mathrm{pH}>6.5$ and $\mathrm{pH}<9.0)$ determined in the joint decree no. 6/2009 IV. 14. KvVM-EüM-FVM (Fig. 7).

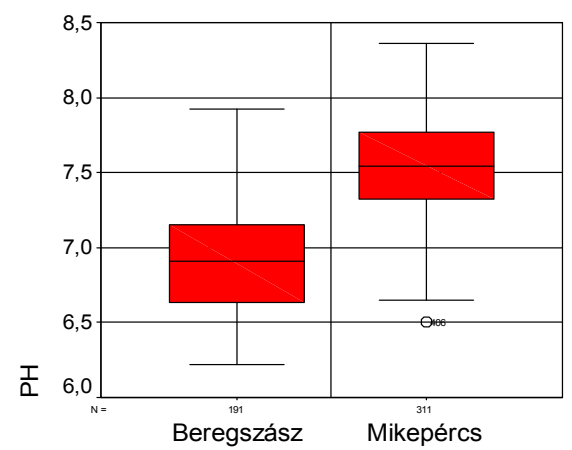

Fig. 7. The $\mathrm{pH}$ of the water samples from Beregszász and Mikepércs regarding the entire research period

In both settlements a maximum in the autumn-winter months and a minimum in the springsummer months can be observed due to the acidic products deriving from the decomposition of organic matter and increasing in the warmer periods (Fig. 8).

\subsubsection{Electric conductivity}

The electric conductivity of the water samples gives the total ion content of the samples (Szabó, 2008; Szalai, 2008). It is observable in Figure 9 that the electric conductivity of the wells was higher in Mikepércs than in Beregszász. In Mikepércs the values were varied between 1000 and $2500 \mu \mathrm{S} / \mathrm{cm}$ but in some wells we measured values above $4000 \mu \mathrm{S} / \mathrm{cm}$. In Beregszász electric conductivity values were generally between 1000 and $1300 \mu \mathrm{S} / \mathrm{cm}$ but in the case of the well 4 we usually measured values above $3000 \mu \mathrm{S} / \mathrm{cm}$ that indicates serious pollution.

There are significant differences between the studied areas inside the settlements. However, if the temporal changes of the contamination of a well are examined, we can say that 
contrary to most of the examined water chemistry parameters the values of electric conductivity are not too variable as it can be seen in Figure 10.

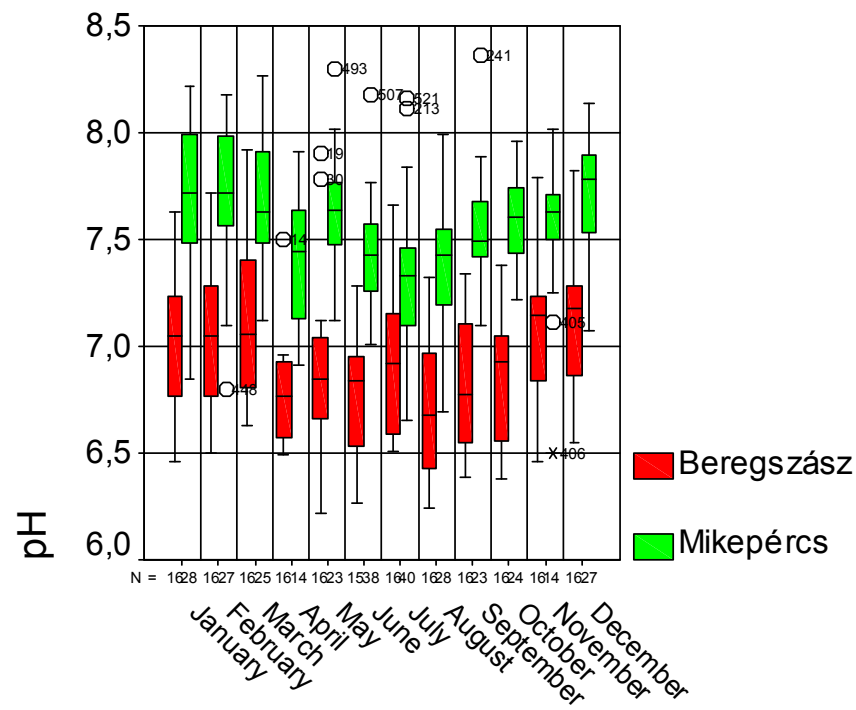

Fig. 8. The seasonal changes of the $\mathrm{pH}$ in the studied settlements

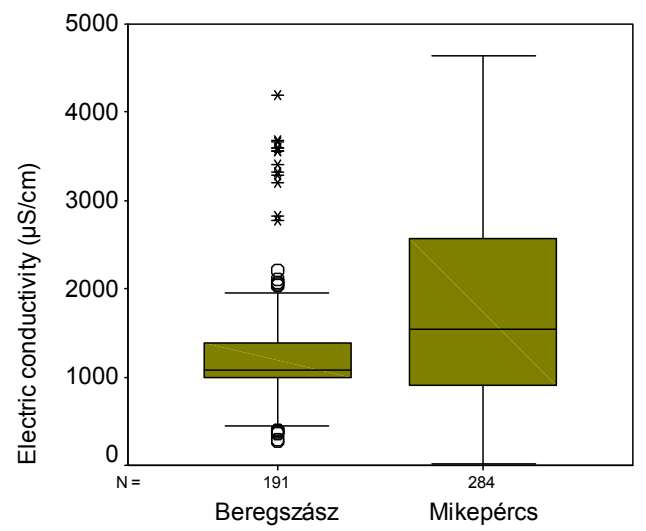

Fig. 9. Electric conductivity in the studied settlements regarding the entire research period (extreme values are not represented)

Following $\mathrm{pH}$, this parameter has the least relative deviation, it slightly exceeded $20 \%$. Although, based on the high value of electric conductivity we cannot determine which ion is mainly responsible for the high value; correlation analyses showed that there is a relatively strong positive correlation between electric conductivity and nitrite content $(\mathrm{r}=0.62, \mathrm{p}<0.01)$. Earlier, significant correlation was proven between electric conductivity and nitrate concentration in the cases of several settlements (Szabó et al., 2010). 


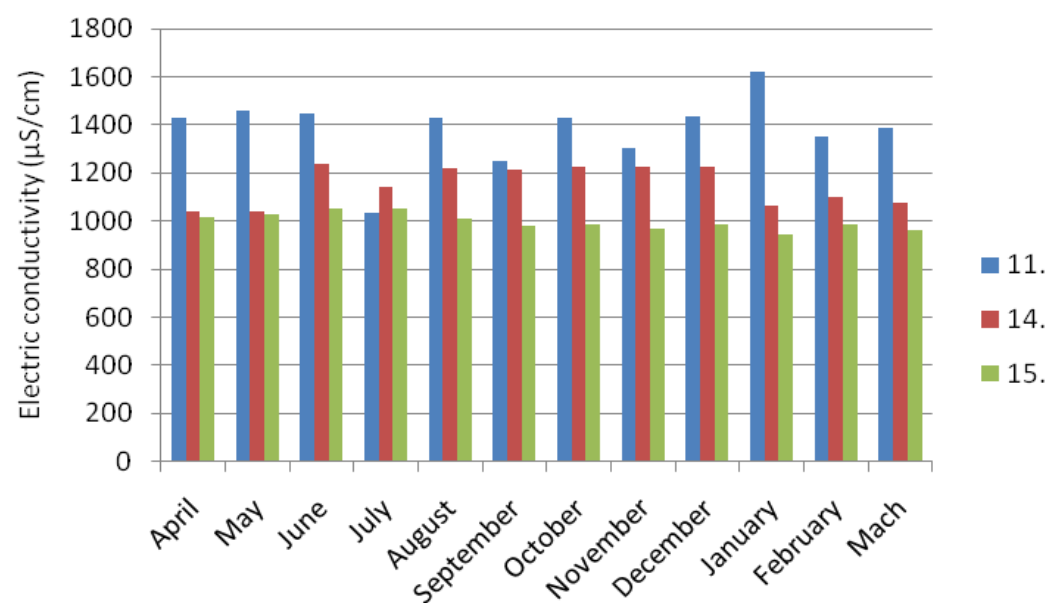

Fig. 10. The temporal changes of electric conductivity in the cases of the wells 11, 14 and 15, Beregszász

\subsubsection{Ammonium ion}

The ammonium ion concentration of the shallow groundwater originated from the biodegradation of organic matter, so it is one of the most important indicators of the organic contaminations. In water, ammonia can take up and also release protons. The percentage of the ammonia and ammonium ion in water bodies depends on the temperature and the $\mathrm{pH}$ of the water (Barótfi, 2000). With the increase of the $\mathrm{pH}$ and the temperature, the concentration of the toxic ammonia also increases. Most of the samples from Mikepércs are neutral or slightly alkaline, but the samples from Beregszász were mainly neutral or slightly acidic. The temperatures of the water samples varied between $4^{\circ} \mathrm{C}$ and $18^{\circ} \mathrm{C}$. In this range of $\mathrm{pH}$ and temperature the percentage of ammonium ion is $97-100 \%$, thus the percentage of the toxic, free ammonia is below 3\%, in the cases of the samples from Beregszász it does not even reach $1 \%$ due to the lower $\mathrm{pH}$.

It is observable in Figure 11 that the wells in Mikepércs are more polluted with ammonium. However, if we examine what percentage of the samples is below the critical contamination (B) limit (0.5 mg/l; according to the joint decree no. 6/2009), there is only a small difference between the two settlements. $34.5 \%$ of the samples in Beregszász, and 28.3\% in Mikepércs contained less ammonium than the contamination limit value.

There is difference between the two settlements in the rate of contamination. In Mikepércs, there are more samples that exceeded many times the contamination limit, $3 \%$ of the samples exceeded more than a hundred times the contamination limit. In Beregszász, only one well contained ten times more ammonium than the contamination limit, but in Mikepércs half of the wells did.

Especially high ammonium ion concentration means anthropogenic contamination, and the extreme contamination values indicate direct sewage infiltration. Besides the domestic 
sewage, the improper treatment of the manure deriving from livestock farming could also contribute to the extreme values.

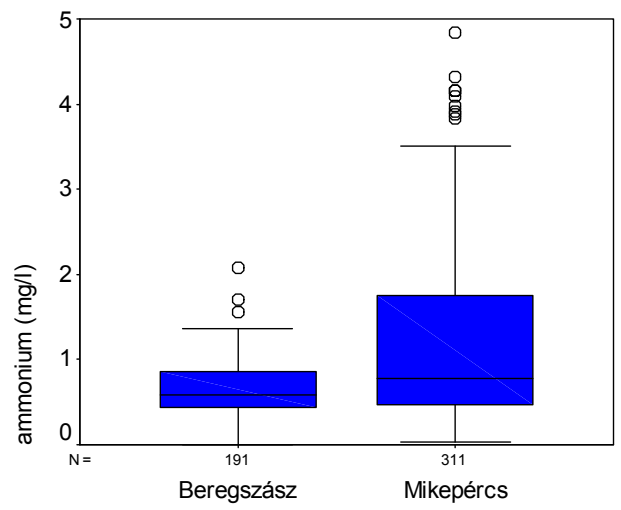

Fig. 11. The ammonium concentration of the water samples in the examined settlements (excluding extreme values)

The highest ammonium concentrations were measured in the autumn-winter months (Fig. 12). In these seasons the degradation of the organic nitrogen occurs, but the oxidization of the ammonium to nitrite is detained by the cold since the activity of the nitrifying bacteria slows down below $10^{\circ} \mathrm{C}$, thus ammonium ions accumulates in the water (Bíró et al., 1998).

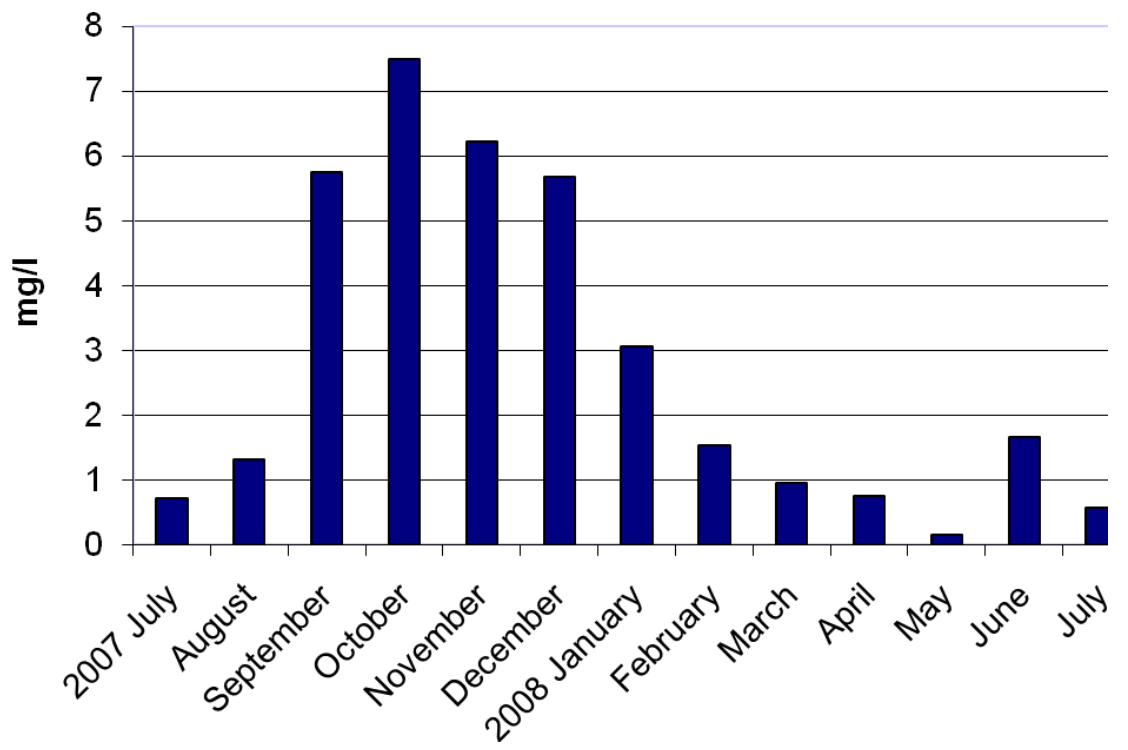

Fig. 12. The ammonium concentrations in Mikepércs in the second research period, based on the averages of 13 wells. (The figure does not contain the data of the well MP19 since extreme high concentrations were measured in this well.) 


\subsubsection{Nitrite}

The next step of the organic matter degradation is the ammonia-nitrite transformation that is a $\mathrm{pH}$-dependent process; it is the fastest between $\mathrm{pH} 8$ and $\mathrm{pH}$ 9.5. In Mikepércs, the conditions are better for the transformation due to the higher $\mathrm{pH}$ of the water. Water temperature also plays an important role since the nitrifying bacteria do not stand cold, their activity slows down below $10^{\circ} \mathrm{C}$, but with the increase of the temperature the nitrite concentration also increases (Barótfi, 2000). It is observable in Figure 13 where the results of the examinations in Mikepércs can be seen. The nitrite concentration of the shallow groundwater decreases significantly in the colder autumn and winter months, the maximum values are measured in the summer months. Among the examined water quality parameters nitrite showed the greatest temporal variability. In some wells of Mikepércs the relative deviation of the nitrite content was generally above $100 \%$, and in Beregszász the mean relative deviation was $83.5 \%$. Nitrite does not accumulate in high concentrations since it immediately oxidizes to nitrate under aqueous conditions.

The joint decree no. 6/2009 does not determine the contamination limit of nitrite in underground water. In surface water bodies $0.3 \mathrm{mg} / 1$ nitrite concentration indicates extremely contaminated water (MSZ 12749/1993). Regarding nitrite contamination, the situation is worse in Mikepércs, although nitrite concentration was below $0.3 \mathrm{mg} / 1$ in $78.4 \%$ of the samples. Extreme nitrite contamination was observed in only one well (MP19) where ammonium concentration was also extremely high. In Beregszász, 92.6\% of the samples contained less nitrite than $0.3 \mathrm{mg} / \mathrm{l}$. In fact, we measured extreme values only in the wells where ammonium concentration was also high.

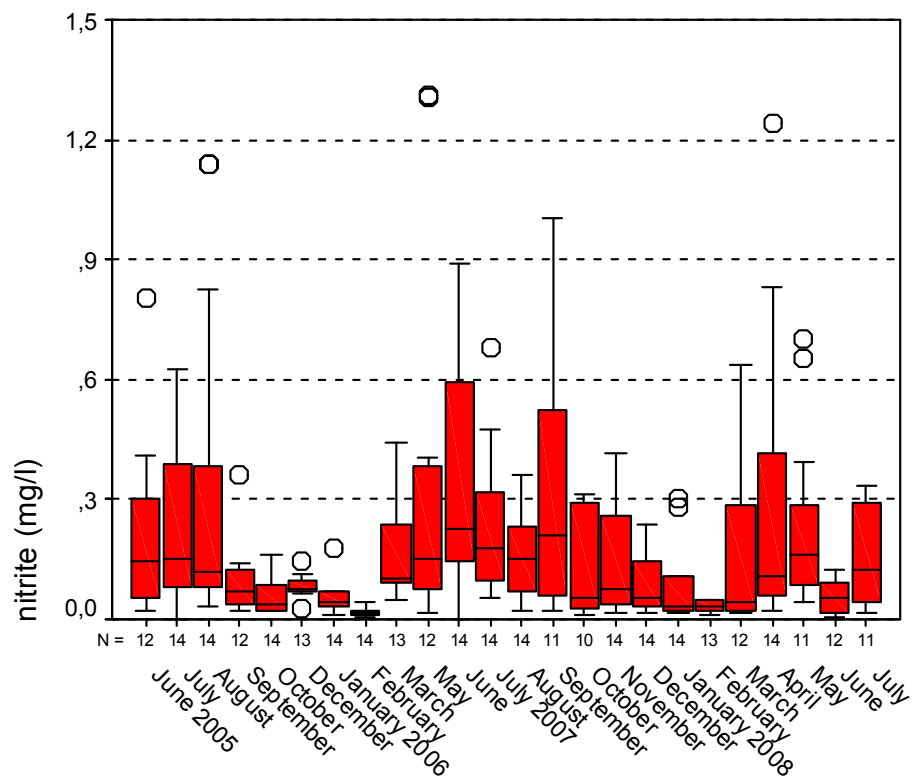

Fig. 13. The nitrite concentration of the water samples from shallow groundwater wells in Mikepércs, in the two research period (Extreme values are not represented) 


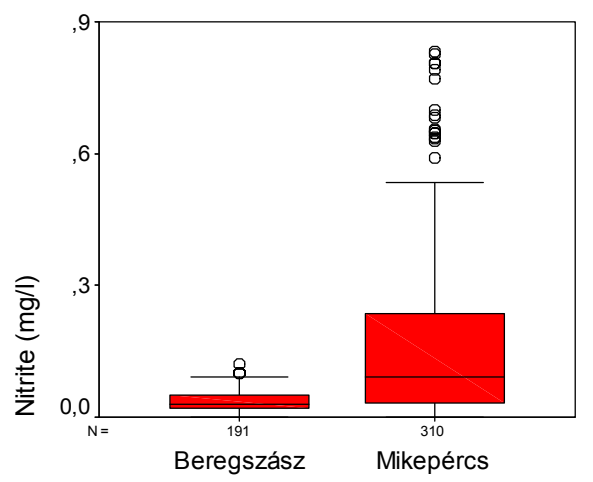

Fig. 14. The nitrite concentration of the water samples in the examined settlements (excluding the extreme values)

\subsubsection{Nitrate}

After the ammonium-nitrite transformation the next step of the organic matter degradation is the oxidization of nitrite to nitrate. During this process, the concentration of the dissolved oxygen in the shallow groundwater decreases considerably (Barótfi, 2000). In Figure 15, the changes of nitrogen forms in the shallow groundwater can be seen in the well no. 2, Beregszász. It is common that ammonium and nitrite concentrations vary inversely to each other since ammonium oxidizes to nitrite, then to nitrate so it is natural that when the concentration of ammonium decreases, the quantity of nitrate increases.

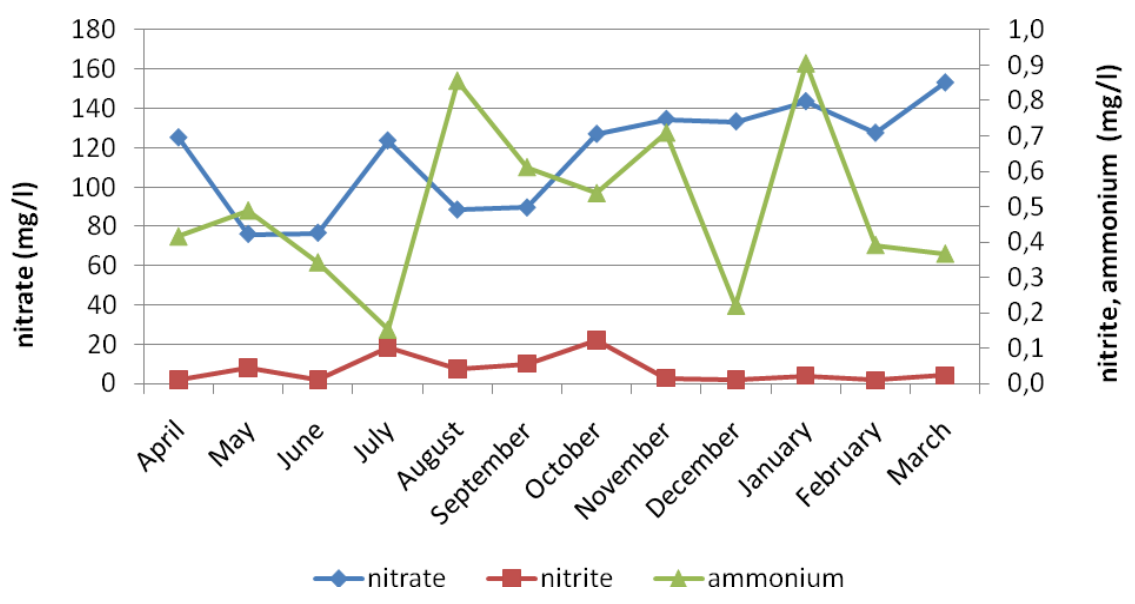

Fig. 15. The changes of the nitrate, nitrite and ammonium concentrations in the well no. 2, Beregszász

Similarly to the other examined water quality parameters, the situation is worse in Mikepércs regarding nitrate (Fig. 16). The mean nitrate concentration of the shallow 
groundwater is $154.4 \mathrm{mg} / 1$ here, while in Beregszász it was only $57.2 \mathrm{mg} / 1$. However, this relatively low value also exceeds the contamination limit $(50 \mathrm{mg} / \mathrm{l})$ determined by the joint decree 6/2009 and the directive on nitrates no. 91/676/EEC. In Mikepércs, nitrate concentration exceeded the limit value in $83 \%$ of the water samples, and more than $20 \%$ of the samples contained more than $250 \mathrm{mg} / 1$ nitrate. Moreover, there were values over 500 $\mathrm{mg} / \mathrm{l}$. However, in Beregszász only $27 \%$ of the samples contained more nitrate than the limit value, and more concentration than $170 \mathrm{mg} / \mathrm{l}$ was not measured in any sample.

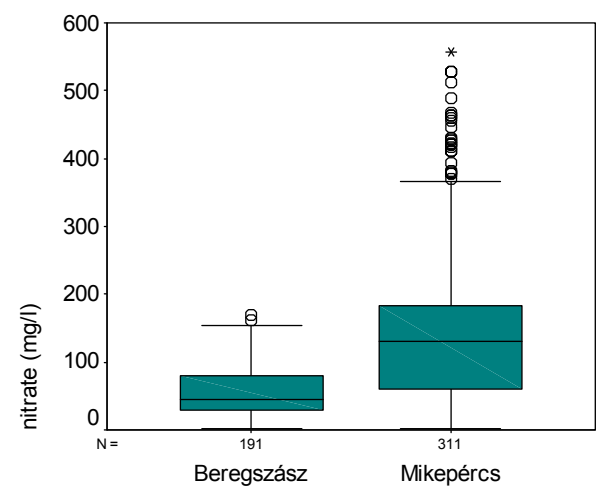

Fig. 16. The nitrate concentration of the water samples in the examined settlements

In the examined settlements the nitrate contamination of the shallow groundwater derived from the domestic sewage, but in Mikepércs fertilizers containing nitrogen scattered in the vegetable gardens and ploughlands near the wells can also contribute to the higher concentrations (Szabó et al., 2010).

\subsubsection{Orthophosphate}

Although, the phosphorus content of the shallow groundwater can derive from natural sources, higher concentrations are always due to anthropogenic effects. The most significant pollution source is domestic sewage, but the residuals of the fertilizers containing phosphorus can also cause contamination (Szabó et al., 2007).

There are great differences between the two settlements regarding orthophosphate contamination (Fig. 17).

In Beregszász the mean of the results is $0.56 \mathrm{mg} / \mathrm{l}$, and only $27.7 \%$ of the samples exceeded the $0.5 \mathrm{mg} / 1$ contamination value (B) determined in the decree no. 6/2009. However, in Mikepércs the mean value was $3.21 \mathrm{mg} / 1$ and almost $94 \%$ of the samples contained more orthophosphate than the contamination limit. The situation is bad since $1 / 5$ of the samples contained ten times more orthophosphate than the contamination limit. Although the situation is much better in Beregszász, more than $1 / 4$ of the wells is considered to be polluted but it is far less than the contamination experienced in Mikepércs.

The unfavourable conditions in Mikepércs occurred because the sewer network was not constructed in the research period. On the other hand, the water table is very close to the 
surface, and it occurred in several times during the research period that the bottom level of the sewage tanks in the surroundings of the wells was under the water table, therefore sewage could directly mixed with the shallow groundwater.

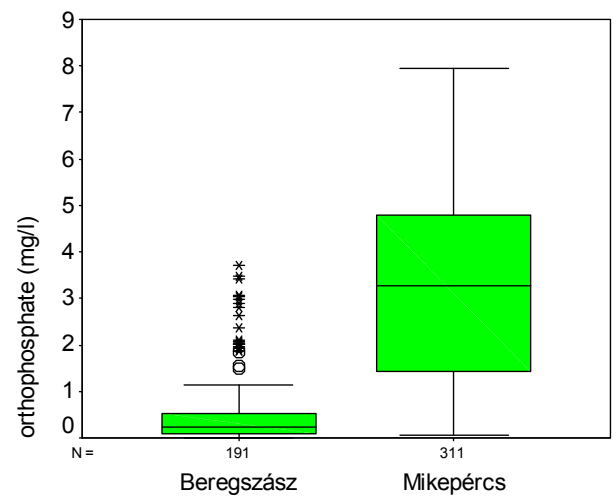

Fig. 17. Orthophosphate concentration of the water samples in the examined settlements

\subsection{The health risks related to the use of groundwater}

Health risks must be examined depending on the use of shallow groundwater. Based on our questionnaire survey in the settlements, it is proven that in Beregszász $81 \%$ of the inhabitants, who live near the wells, generally consume the water of the wells; but in Mikepércs it does not happen (except some cases). The inhabitants in Beregszász are in greater danger in terms of human health. However, Mikepércs is more endangered in terms of animal heath since the contamination of the dug wells is higher than in Beregszász, and water from the wells is used for watering animals in almost every household. In Beregszász only $1 / 3$ of the wells are used for this purpose.

Human and animal health risk can be estimated based on the comparison of the values measured in the examined water samples and the threshold limit values related to drinking water and water for animals. (The evaluation was carried out based on the Hungarian threshold limit values.) The threshold limit values of drinking water are clear, but the law is not obvious regarding water for animals.

\subsubsection{Human health risks}

According to the part B of the Appendix 1 of the Government Decree No. 201/2001. (X. 25.) on the water quality requirements, the threshold limit value is $50 \mathrm{mg} / 1$ for nitrate and 0.5 $\mathrm{mg} / \mathrm{l}$ for nitrite. In the part $\mathrm{C}$ of the Appendix 1 of the government decree the threshold limit values for indicator water quality characteristics can be found. It is $2500 \mu \mathrm{S} / \mathrm{cm}$ for electric conductivity, and the range between 6.5 and 9 can be considered acceptable regarding $\mathrm{pH}$. The $\mathrm{D}$ part of the Appendix 1 of the decree describes threshold limit values for karstic water, shallow groundwater and bank-filtered water resources. According to this, if drinking water is provided from these water resources, the threshold limit value for ammonium is $0.2 \mathrm{mg} / \mathrm{l}$, and it is $0.1 \mathrm{mg} / \mathrm{l}$ for nitrite. 
Regarding the threshold limit values it is proven that none of the examined wells in Mikepércs meets the requirements. In the cases of the examined water quality parameters we measured values that exceeded the threshold limit values many times, therefore the water of the wells are absolutely inappropriate for human consumption.

In Beregszász, the water quality of the wells was much better, but $4 / 5$ of the inhabitants regularly consume water from the wells. It is also observable that we can often find values that exceed the threshold limit value. Electric conductivity was higher than the limit value only in $6.8 \%$ of the samples, the percentages of the values above the limit value were $10.2 \%$ regarding $\mathrm{pH}, 15.7 \%$ for nitrite, $27.7 \%$ examining orthophosphate and $45.2 \%$ regarding nitrate. In case of ammonium, $92.1 \%$ of the samples contained higher concentration than the limit value, if we consider the threshold limit value determined for shallow groundwater $(0.2 \mathrm{mg} / \mathrm{l})$. However, if we would consider the threshold limit value regarding deep groundwater $(0.5 \mathrm{mg} / \mathrm{l})$, the percentage would even be $65.4 \%$. If we examine the wells in Beregszász one by one, it is observable that there was not a single well where at least one value of the examined parameters did not exceed the limit value. Regarding all the examined water quality parameters, the values of only $2.6 \%$ of the 191 water samples from Beregszász were below the threshold limit values. These data are alarming, even if the water of the wells in Beregszász is less contaminated than the water of the wells in Mikepércs, since if someone regularly drinks water that contains harmful components in higher concentration, they must reckon with the risks of illnesses.

The effects of nitrate and nitrite on health are the mostly studied issues of the special literature. In some cases such as methemoglobinemia the process of the illness and the effects of the intoxication are well-known, but in other cases (such as the formation of stomach cancer) the role of nitrate and nitrite is not clear (Barótfi, 2000; Du et al., 2007; Kerényi, 1995; Milkowski et al., 2010; Yang et al., 2007).

Methemoglobinemia (or "blue baby" syndrome) occurs mostly in infants. The $\mathrm{pH}$ of the stomach is almost neutral in infants - contrary to the acidic $\mathrm{pH}$ of the adults' stomach -, and this is beneficial for the bacteria that transforms nitrate to nitrite. Nitrite reacts with haemoglobin forming methemoglobin, thus it blocks the oxygen carrying capacity of blood and can cause suffocation (Barzilay et al., 1999). In adults, there is a specific enzyme that transforms methemoglobin back to haemoglobin so it can detoxify the body. This enzyme appears later during the growth of the child, so in infants the detoxification do not occur (Barótfi, 2000). In the case of nitrate concentration above $50 \mathrm{mg} / 1$ this illness can occur in infants, therefore in Beregszász people must not give the water of dug wells to infants since less than $50 \mathrm{mg} / 1$ nitrate concentration was measured only in 3 of the examined 16 wells.

\subsubsection{Animal health risks}

The decree no. 41/1997. (V. 28.) states that "As far as possible water of drinking-water quality should be used for the watering of animals." Thus, the decree do not make the use of drinking water obligatory, just says that as far as possible water of drinking water must be used. Unfortunately, it was not carried out in the cases of the examined households (possessing dug wells) in Mikepércs since the inhabitants water the animals everywhere with the water from the dug wells, but the quality of this water is not adequate regarding the directions. On the other hand, they had the possibility to use water of drinking water 
quality as the water supply system is entirely constructed in the settlement. However, they do not use drinking water due to financial and comfortable causes. The situation is similar in Beregszász: people also used the water of the dug wells to water animals, but in several cases tap-water was not available, and it is also true that where the water supply system is constructed people also do not give tap-water to the animals.

Knowing the water quality of the wells in Mikepércs, we can say that the use of water from the dug wells mean serious risk to animal health since we measured values that exceeded the threshold limit values many times regarding several water quality parameters. It is often proved that, due to some contaminants, in animals the same illnesses can arise as in humans, such as methemoglobinemia. In the case of ruminant animals symptoms similar to the infants' symptoms appear due to the consumption of water containing nitrate in high concentration (Barzilay et al., 1999). An international research group examined the effect of nitrate on human and animal organisms. They proved that besides ruminant animals, pigs are also endangered by methemoglobinemia since they cannot produce enough $\mathrm{MetHb}-$ reductase enzyme that transforms methemoglobin to haemoglobin (Cockburn et al., 2010). The research group also studied what risks are caused if nitrite indirectly gets into the human body through animal source foods such as milk, eggs, or meat. According to the examinations only $2.9 \%$ of the accepted nitrite load per day gets into the human body with animal source foods. Therefore, the authors state that the consumption of animal source foods containing nitrite does not mean serious health risk to human health. However, regarding several other contaminants (e. g. heavy metals) we must consider the process of bioaccumulation since in the higher levels of the food chain such accumulation can occur that can mean serious risk to human health.

Since in Beregszász water of drinking water quality is not ensured for animals, some risks must be considered, especially in the cases of the wells where significant contamination was experienced regarding some parameters (wells no. 2, 7, 10 and 16). However, comparing to Mikepércs, we can say that the risks to animal health are far less in Beregszász.

\section{Conclusion}

The water quality of dug wells and the factors influencing water quality were studied in two settlements with different natural and social-economic characteristics. Beregszász is in better situation in terms of the natural characteristics and the anthropogenic effects influencing water quality since the water table can be found deeper, and the water permeability of the soils is worse here. The sewer network is partly constructed in Beregszász, and the role of livestock farming and gardens, that endanger the quality of shallow groundwater, is less.

Our presumption that the water quality of the dug wells is better in Beregszász (that have more advantageous characteristics) is proven. In the cases of all the examined contaminants (ammonium, nitrite, nitrate, orthophosphate) we proved that the contamination of the water of the wells was much more significant in Mikepércs. Based on the results we can say that among the factors influencing shallow groundwater quality the grain size distribution, then the depth of the shallow groundwater play the most important role, so mainly natural characteristics affect the water quality of the dug wells.

Studying the risks of the use of water from the dug wells it is proven that there are health risks in both settlements. Mainly risks to human health are significant in Beregszász since 
$80 \%$ of the inhabitants living in the surroundings of the examined wells regularly consume the water of the wells, while there was not a single well where at least one value of the examined parameters did not exceed the limit value. In Mikepércs, the inhabitants do not consume water from the wells, but $86 \%$ of the wells are used to water animals. This means extremely serious risk to animal health since the water of the wells in Mikepércs is absolutely inappropriate for animal consumption (due to the serious contamination).

\section{Acknowledgement}

The research was supported by the No. 68566 Hungarian Research Found (OTKA), the MERIDIÁN Landscape and Environmental Geography Foundation and the TÁMOP4.2.2/B-10/1-2010-0024 Hungarian Found

\section{References}

Adekunle, I.M.; Adetunji, M.T; Gbadebo, A.M. \& Banjoko, O.B. (2007). Assessment of Groundwater Quality in a Typical Rural Settlement in Southwest Nigeria. Int. J. Environ. Res. Public Health, 4(4), pp. 307-318.

Ballenegger, R. \& Di Gléria, J. (1962). Soil and manure examination methods, Mezőgazdasági Kiadó, Budapest, Hungary (in Hungarian)

Barótfi, I. (2000). Environmental technology - Mezőgazda Kiadó, ISBN 963-286-009-8-9, Budapest, Hungary (in Hungarian)

Barzilay, J.; Weinberg, W.G. \& Eley, J.W. (1999). The Water We Drink, Rutgers University Press, ISBN 0-8135-2673-6, New Brunswick, USA

Bíró, T.; Thyll, Sz. \& Tamás, J. (1998). Risk assassment of nitrate pollution in lower watershed of the Berettyó River. In: Filep, Gy. (ed.): Soil water environment relationships. Wageningen, Holland - Debrecen, Hungary

Campbell, G. S. (1985). Soil Physics with Basics, Transport Models for Soil-Plant Systems, Development in Soil Science 14, Elsevier, 149 p. ISBN 0-444-42557-8

Cey, E.E.; Rudolph, D.L.; Aravena, R. \& Parkin, G. (1999). Role of the riparian zone in controlling the distribution and fate of agricultural nitrogen near a small stream in southern Ontario. Journal of Contaminant Hydrology 37, pp. 45-67.

Chettri M. \& Smith G.D. (1995). Nitrate pollution in groundwater in selected districts of Nepal. Hydrogeology Journal 3, pp. 71-76.

Cockburn, A; Brambilla, G.; Fernández, M.L.; Arcella, D.; Bordajandi, L.R.; Cottrill, B.; Peteghem, C. \& Dorne, J.L. (2010) Nitrite in feed: From Animal health to human health. (Aricle in press, August 2011) Toxicology and Applied Pharmacology. Available from http:/ / www.sciencedirect.com/science

Council Directive of 12 December 1991 concerning the protection of waters against pollution caused by nitretes from agricultural sources (91/676/EEC)

Decree no. 41/1997. (V. 28.) FM on Veterinary regulation, Available from http:// www.magyarorszag.hu (in Hungarian).

Du, S.T.; Zhang, Y.S. \& Lin, X.Y. (2007) Accumulation of Nitrate in Vegetables and its Possible Implications to Human Health. Agricultural Sciences in China, 6 (10), pp. 1246-1255. 
Goss, M.J.; Barry, D.A.J. \& Rudolph, D.L. (1998). Contamination in Ontario farmstead domestic wells and its association with agriculture: 1 . Results from drinking water wells. Journal of Contaminant Hydrology 32, pp. 267-293.

Government Joint Decree No. 6/2009. (IV. 14.) KvVM-EüM-FVM on limit values established for the protection of groundwater and the geological medium, 2009. (in Hungarian)

Howden, N.J.K.; Bowes, M.J.; Clark, A.D.J.; Humphries, N. \& Neal, C. (2009). Water quality, nutrients and the European union's Water Framework Directive in a lowland agricultural region: Suffolk, south-east England. Science of the Total Environment 407, pp. 2966-2979.

Hungarian Standard no. MSZ 12749 1993, The quality of surface water, qualitative characteristics and qualification, 1993 (in Hungarian)

Jang, C.S. \& Liu, C.W. (2005). Contamination potential of nitrogen compounds in the heterogeneous aquifers of the Choushui River alluvial fan, Taiwan. Journal of Contaminant Hydrology 79, pp. 135-155.

Knobeloch, L.; Salna, B.; Hogan, A.; Postle, J. \& Anderson, H. (2000). Blue babies and nitratecontaminated well water. Environ Health Perspect 108, pp. 675-678.

Milkowski, A.; Garg, H.K.; Coughlin, J.R. \& Bryan, N.S. (2010). Nutritional epidemiology in the context of nitric oxide biology: A risk-benefit evaluation for dietary nitrite and nitrate. Nitric Oxide 22, pp. 110-119.

Molnár, J. (2009). General information and geographic position. In: Kárpátalja - A Kárpátmedence régiói 11. Baranyi, B. (Ed.) Dialóg Campus Kiadó, ISBN 9789639899186, Pécs-Budapest, Hungary (in Hungarian)

MSZ 'Determination of organic carbon content of the soil' Hungarian Standard No. 08-0210; 1977 (in Hungarian).

MSZ 'Examination of some chemical characteristics of the soil' Hungarian Standard No. 080206-2; 1978a (in Hungarian).

MSZ 'Examination of the physical and water management characteristics of the soil' Hungarian Standard No. 08-0205; 1978b (in Hungarian).

Muñoz-Carpena, R.; Ritter, A. \& Li, Y.C. (2005). Dynamic factor analysis of groundwater quality trends in an agricultural area adjacent to Everglades National Park. Journal of Contaminant Hydrology 80, pp. 49-70.

Nyizsalovszki, R. \& Szabó, Sz. (2003). The temporal and spatial changes of water table in a piedmont sample area. Hungarian Geographical Bulletin 52, (1-2) pp. 23-36. (in Hungarian)

Oprean, L.; Poplăcean, M.; Oancea, S.; Oprean, C. \& Lengyel, E. (2009). Monitoring the microbiological and physico-chemical pollution degree of the river Visa. Studia Universitatis "Vasile Goldiş", Seria Ştiințele Vieții, Vol. 19, issue1, pp. 203-207.

Pál, Z.; Aczél, M. \& Pál, K. (2009). Nitrate contamination of the groundwater in rural settlements - example of Imecsfalva. Collegium Geographicum 6. sz. pp. 43-51. (in Hungarian with english abstract)

Rakonczai, J. (2008). Global environmental issues. Universitas Szeged Kiadó, ISBN 9639416525, Szeged, Hungary (in Hungarian)

Steiner, F. (Ed.) (2010) The state of the environment in Hungary, Prospektus Nyomda, Budapest, Hungary (in Hungarian)

Sultana, F. (2011). Suffering for water, suffering from water: Emotional geographies of resource access, control and conflict. Geoforum 42, pp. 163-172. 
Szabó Gy.; Szabó Sz.; Szabó A. \& Szemán B. (2007). Spatial and time variations of the groundwater quality of two different landscapes, In: Implementation of Landscape Ecology in New and Changing Conditions, Boltižiar, M. (ed.), ILE Slovak Academy of Sciences, pp. 421-427. ISBN 978-80-89325-03-0

Szabó, Gy.; Angyal, A.; Csikós, A.; Bessenyei, É.; Tóth, E.; Kiss, P.; Csorba, P. \& Szabó, Sz. (2010) Examination of the groundwater pollution at lowland settlements - Studia Universitatis "Vasile Goldiş", Seria Ştiințele Vieții Vol. 20, issue 4, pp. 89-95. ISSN: 1584-2363

Szabó, Sz. (2008). Examination methods of environmental protecion - monitoring - távoktatási tankönyv, Debrecen, Hungary (in Hungarian)

Szalai, Z.; Jakab, G. \& Madarász, B. (2004). Estimating the vertical distribution of groundwater $\mathrm{Cd}$ and $\mathrm{Cu}$ contents in alluvial sediments (River Danube). Saturated and Unsaturated Zone; In: Integration of process knowledge into effective models. (Eds. Per Aagard et al.) pp. 303-312. La Gordialica Pavese, Rome, Italy

Szalai, Z. (2008). Spatial and temporal pattern of soil $\mathrm{pH}$ and Eh and their impact on solute iron content in a wetland (Transdanubia, Hungary) AGD Landscape and Environment 2 (1). pp. 34-45. HU ISSN 1789-4921

Yang, C.Y.; Wu, D.C. \& Chang, C.C. (2007) Nitrate in drinking water and risk of death from colon cancer in Taiwan. Environment International 33, pp. 649-653.

Warner, N.R.; Levy, J.; Harpp, K. \& Farruggia, F. (2008). Drinking water quality in Nepal's Kathmandu Valley: a survey and assessment of selected controlling site characteristics. Hydrogeology Journal 16, pp. 321-334.

Widory, D.; Kloppmann, W.; Chery, L.; Bonnin, J.; Rochdi, H. \& Guinamant, J.L. (2004). Nitrate in groundwater: an isotopic multi-tracer approach. Journal of Contaminant Hydrology 72, pp. 165-188. 


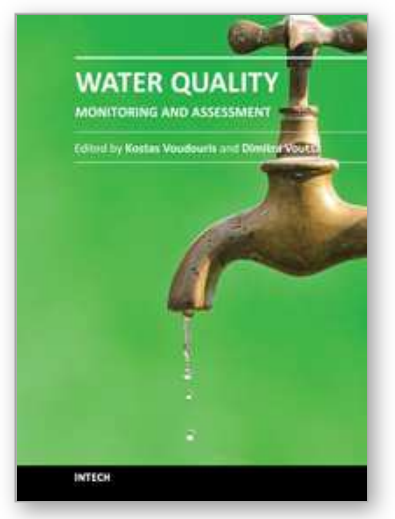

\author{
Water Quality Monitoring and Assessment \\ Edited by Dr. Voudouris
}

ISBN 978-953-51-0486-5

Hard cover, 602 pages

Publisher InTech

Published online 05, April, 2012

Published in print edition April, 2012

The book attempts to covers the main fields of water quality issues presenting case studies in various countries concerning the physicochemical characteristics of surface and groundwaters and possible pollution sources as well as methods and tools for the evaluation of water quality status. This book is divided into two sections: Statistical Analysis of Water Quality Data;Water Quality Monitoring Studies.

\title{
How to reference
}

In order to correctly reference this scholarly work, feel free to copy and paste the following:

Gyorgy Szabo, Tímea Vince and Eva Bessenyei (2012). Study of the Factors Influencing the Shallow Groundwater Quality in Two Settlements with Different Characteristics, Water Quality Monitoring and Assessment, Dr. Voudouris (Ed.), ISBN: 978-953-51-0486-5, InTech, Available from:

$\mathrm{http}: / / w w w . i n t e c h o p e n . c o m / b o o k s / w a t e r-q u a l i t y-m o n i t o r i n g-a n d-a s s e s s m e n t / s t u d y-o f-t h e-f a c t o r s-i n f l u e n c i n g-$ the-shallow-groundwater-quality-in-two-settlements-with-different-c

\section{INTECH}

open science | open minds

\author{
InTech Europe \\ University Campus STeP Ri \\ Slavka Krautzeka 83/A \\ 51000 Rijeka, Croatia \\ Phone: +385 (51) 770447 \\ Fax: +385 (51) 686166 \\ www.intechopen.com
}

\author{
InTech China \\ Unit 405, Office Block, Hotel Equatorial Shanghai \\ No.65, Yan An Road (West), Shanghai, 200040, China \\ 中国上海市延安西路65号上海国际贵都大饭店办公楼 405 单元 \\ Phone: +86-21-62489820 \\ Fax: $+86-21-62489821$
}


(C) 2012 The Author(s). Licensee IntechOpen. This is an open access article distributed under the terms of the Creative Commons Attribution 3.0 License, which permits unrestricted use, distribution, and reproduction in any medium, provided the original work is properly cited. 